\title{
Association between anthropometric parameters and carotid intima-media thickness in obese adolescents
}

\author{
*Nur Aisiyah Widjaja ${ }^{1}$, Rendi Aji Prihaningtyas ${ }^{1}$, Meta Herdiana Hanindita ${ }^{1}$, Roedi Irawan ${ }^{1}$, Retno \\ Handajani $^{1}$, IDG Ugrasena ${ }^{1}$
}

Sri Lanka Journal of Child Health, 2021; 50(1): 28-31

\begin{abstract}
Introduction: Prevalence of obesity among adolescents is increasing in developing countries. Inflammation in obesity causes atherosclerosis which could develop into cardiovascular disease. Carotid intima-media thickness (CIMT) is a noninvasive subclinical marker of atherosclerosis. Determining the association between body size and atherosclerosis may allow early detection of atherosclerosis risk.
\end{abstract}

Objectives: To assess the association between anthropometric parameters and CIMT in obese adolescents.

Method: A cross sectional study was conducted on adolescents with central obesity who visited the paediatric clinic of Dr. Soetomo General Hospital, Surabaya, Indonesia. Eating habits were obtained through food recall. Weight, height, waist circumference and thigh circumference were measured for calculation of body mass index (BMI) and waist to hip ratio (WHR). Obesity was defined as $\mathrm{BMI}>\mathrm{P}_{95}$ according to age and sex. CIMT was obtained through B mode ultrasonography on the neck. Analysis was done using Spearman rho' to analyse association between BMI, waist circumference, WHR and CIMT.

Results: There were 59 obese adolescents, comprising $32(54.2 \%)$ males and 27 (45.8\%) females. BMI, waist circumference and WHR were not significantly associated with CIMT in obese adolescents $(\mathrm{p}>0.05)$.

${ }^{1}$ Airlangga University, Surabaya, Indonesia
*Correspondence: nuril08@yahoo.com

(iD) https://orcid.org/0000-0002-4253-8760

(Received on 13 February 2020: Accepted after revision on 20 March 2020)

The authors declare that there are no conflicts of interest

This research received a grant from Airlangga University, Surabaya, Indonesia.

Open Access Article published under the Creative

Commons Attribution CC-BY (C) (i) License
Conclusions: In this study, BMI, waist circumference and WHR were not significantly associated with CIMT in obese adolescents.

DOI: http://dx.doi.org/10.4038/sljch.v50i1.9398

(Key words: Obesity, CIMT, BMI, waist circumference, waist to hip ratio)

\section{Introduction}

In Indonesia, the prevalence of obesity is increasing among all age groups, including adolescents ${ }^{1}$. The high level of body fat in obesity, is a risk factor for cardiovascular disease ${ }^{2}$. Atherosclerosis starts in obese children and adolescents ${ }^{3}$. Central obesity correlates positively with atherosclerosis progressivity, although the correlation is still inconsistent ${ }^{4}$. Carotid intima-media thickness (CIMT) is a subclinical atherosclerosis marker and a risk factor for cardiovascular disease that could be measured non-invasively and easily ${ }^{5,6}$. However, most studies on this subject have been done in adults in developed countries.

\section{Objectives}

To assess the association between body mass index (BMI), waist circumference, waist to hip ratio (WHR) and CIMT in obese adolescents.

\section{Method}

A cross sectional study was carried out on obese adolescents, 13-16 years of age, at the paediatric clinic of Dr. Soetomo General Hospital, Surabaya, Indonesia. Exclusion criteria comprised consumption of steroids within 6 months before study, dyslipidaemia drugs within 3 months before study, hormonal therapy, alcohol consumption, smoking, and endocrine disorders. Eating habits were obtained through food recall.

Anthropometric measurements: Weight (kg) measurement used a digital scale with subjects wearing light clothes, without footwear or other accessories (Seca, Germany). Height (cm) measurement used a stadiometer, with subjects in erect position with no footwear or headwear (Seca, Germany). For calculation of BMI, the following formula was used. BMI = body weight $(\mathrm{kg}) /$ body height $\left(\mathrm{m}^{2}\right)$. Obesity was defined as BMI $>\mathrm{P}_{95}$ based on age and gender according to CDC 2000 
curve. Waist circumference $(\mathrm{cm})$ was measured parallel to the floor using metlin from upper part of illiac crest and bottom border of ribs on midaxillary line at end of expiration. Thigh circumference was measured from the biggest circumference on the buttocks with parallel position to the floor. WHR was the result of waist circumference $(\mathrm{cm})$ divided by thigh circumference $(\mathrm{cm})$.

CIMT measurement: This was done using B-mode ultrasonography (Toshiba, Japan) by cardiologists. Examination was done in the supine position with the neck extended and bent to the right.

Ethical issues: Ethical approval was obtained from the Ethics Committee of Dr. Soetomo General Hospital, Surabaya, Indonesia (No. 0698/KEPK/ $\mathrm{X} / 2018$ ). Written informed consent was obtained from parents of the subjects before commencing study. All data obtained from the subjects were anonymised.

Statistical analysis: Quantitative parameters are presented as mean \pm standard deviation. Kolmogorov-Smirnov test was utilised to evaluate data normality. Associations between BMI, waist circumference, WHR and CIMT were analysed using Spearman rho' SPSS with significant $\mathrm{p}$ value of $<0.05$.

\section{Results}

There were 59 obese adolescents, comprising 32 $(54.2 \%)$ males and $27(45.8 \%)$ females. The subjects had a mean BMI of $31.99 \pm 3.67 \mathrm{~kg} / \mathrm{m}^{2}$, mean waist circumference of $100.18 \pm 10.63 \mathrm{~cm}$, mean thigh circumference of $105.32 \pm 8.27 \mathrm{~cm}$, and a mean CIMT of $0.51 \pm 0.10 \mathrm{~mm}$ (Table 1$)$.

Table 1: Study subjects' characteristics

\begin{tabular}{|l|c|}
\hline \multicolumn{1}{|c|}{ Variable } & Mean (SD) \\
\hline Age (years) & $13.89 \pm 0.82$ \\
\hline Body weight $(\mathrm{kg})$ & $80.77 \pm 13.35$ \\
\hline Body height $(\mathrm{cm})$ & $158.76 \pm 7.12$ \\
\hline Body mass index $\left(\mathrm{kg} / \mathrm{m}^{2}\right)$ & $31.99 \pm 3.67$ \\
\hline Waist circumference $(\mathrm{cm})$ & $100.18 \pm 10.63$ \\
\hline Thigh circumference $(\mathrm{cm})$ & $105.32 \pm 8.27$ \\
\hline WHR & $0.95 \pm 0.6$ \\
\hline CIMT $(\mathrm{mm})$ & $0.51 \pm 0.10$ \\
\hline
\end{tabular}

No association between BMI, waist circumference, or WHR and CIMT was found in obese adolescents $(\mathrm{p}>0.05)$ (Table 2)

Table 2: Association between variables

\begin{tabular}{|c|c|c|c|}
\hline CIMT & BMI & Waist circumference & WHR \\
\hline $\mathrm{R}$ & 0.019 & -0.163 & -0.032 \\
\hline $\mathrm{P}$ & 0.886 & 0.217 & 0.812 \\
\hline
\end{tabular}

\section{Discussion}

Obesity gives rise to a chronic inflammation because of an imbalance between pro-inflammatory and anti-inflammatory cytokines ${ }^{7}$. The high body fat level at stomach causes cell dysfunction and increases risk of cardiovascular disorder in adulthood ${ }^{2,8,9}$. Waist circumference can assess risk factors for cardiovascular disease in obese adolescents $^{10}$.

Cardiovascular disease starts with atherosclerosis process in obese children and adolescents ${ }^{3}$. Long obesity duration and central obesity are associated with subclinical heart disease ${ }^{11}$. Obese adolescents have increased CIMT in comparison with adolescents having normal $\mathrm{BMI}^{10,12}$. The presence of dyslipidaemia, hypertension, and diabetes mellitus increases CIMT $^{13}$. A previous study showed that left CIMT is better associated with cardiovascular risk compared to right CIMT $^{14}$. In children, no association was found between CIMT and BMI or body fat ${ }^{15}$. However, CIMT tends to increase after the age of 10 due to hormonal changes ${ }^{16,17}$.
This study shows no association between CIMT and BMI, waist circumference, or WHR. This is in accordance with past studies which showed no association between CIMT and BMI or body fat. However, results from a study in a developed country showed that adiposity is associated with CIMT in adolescents ${ }^{18}$. CIMT is associated with waist circumference and WHR in healthy adolescents $^{14}$. In obese adolescents, CIMT is associated with BMI, waist circumference, and body fat percentage ${ }^{10}$.

This study has a number of limitations. Being a cross sectional study, conclusions regarding causal relation could not be drawn. High-resolution Bmode ultrasonography also has low sensitivity and is operator dependent. This could affect the results of CIMT measurements due to undetected small differences ${ }^{17}$. Puberty data were also not available which could have affected the results of this study $^{14}$. 


\section{Conclusions}

In this study, BMI, waist circumference and WHR were not significantly associated with CIMT in obese adolescents

\section{Acknowledgements}

The authors thank the Universitas Airlangga, Surabaya, Indonesia for supporting this study and Dr. Soetomo General Hospital, Surabaya for permitting this study.

\section{References}

1. Rachmi CN, Li M, Alison BL. Overweight and obesity in Indonesia: prevalence and risk factors - a literature review. Public Health 2017; 147:20-9.

https://doi.org/10.1016/j.puhe.2017.02.002 PMid: 28404492

2. Going SB, Lohman TG, Cussler EC, Williams DP, Morrison JA, Horn PS. Percent body fat and chronic disease risk factors in U.S. Children and Youth. American Journal of Preventive Medicine 2011; 41:S77-S86. https://doi.org/10.1016/j.amepre.2011.07.0 06

PMid: 21961616

3. Fang J, Zhang JP, Luo CX, Yu XM, Lv LQ. Carotid Intima-media thickness in childhood and adolescent obesity relations to abdominal obesity, high triglyceride level and insulin resistance. International Journal of Medical Sciences 2011; 7:27883.

https://doi.org/10.7150/ijms.7.278

PMid: 20827427 PMCid: PMC2934726

4. Chagas P, Caramori P, Barcellos C, Galdino TP, Gomes I, Schwanke CHA. Association of different anthropometric measures and indices with coronary atherosclerotic burden. Arq. Bras. Cardiol. 2011; 97:397-401.

https://doi.org/10.1590/S0066782X20110 05000093

PMid: 21971634

5. van den Oord SCH, Sijbrands EJG, ten Kate GL, van Klaveren D, van Domburg RT, van der Steen AFW, Schinkel AFL. Carotid intima-media thickness for cardiovascular risk assessment: Systematic review and meta-analysis. Atherosclerosis 2013; 228:1-11. https://doi.org/10.1016/j.atherosclerosis.20 13.01 .025

PMid: 23395523

6. Gao Z, Khoury PR, McCoy CE, Shah AS, Kimball TR, Dolan LM, et al. Adiposity has no direct effect on carotid intimamedia thickness in adolescents and young adults: Use of structural equation modeling to elucidate indirect \& direct pathways. Atherosclerosis 2016; 246:2935 .

https://doi.org/10.1016/j.atherosclerosis.20 15.11 .033

PMid: 26752690 PMCid: PMC4764416

7. Todendi PF, Possuelo LG, Klinger EI, Reuter CP, Burgos MS, Moura DJ, et al. Low-grade inflammation markers in children and adolescents: Influence of anthropometric characteristics and CRP and IL6 polymorphisms. Cytokine 2016; 88: $177-83$.

https://doi.org/10.1016/j.cyto.2016.09.007 PMid: 27643980

8. Staiano AE, Katzmarzyk PT. Ethnic and sex differences in body fat and visceral and subcutaneous adiposity in children and adolescents. International Journal of Obesity 2012; 36:1261-9.

https://doi.org/10.1038/ijo.2012.95

PMid: 22710928 PMCid: PMC4129655

9. Weber DR, Levitt KLE, Zemel BS, Gallagher PR, Murphy KM, Dumser SM, et al. Anthropometric measures of abdominal adiposity for the identification of cardio-metabolic risk factors in adolescents. Diabetes Research and Clinical Practice 2014; 103:e14-e17. https://doi.org/10.1016/j.diabres.2013.12.0 50

PMid: 24552682 PMCid: PMC4384445

10. Elkiran O, Yilmaz E, Koc M, Kamanli A, Ustundag B, Ilhan $\mathrm{N}$. The association between intima media thickness, central obesity and diastolic blood pressure in obese and overweight children: A crosssectional school-based study. International Journal of Cardiology 2013; 165: 528-32. https://doi.org/10.1016/j.ijcard.2011.09.08 0

PMid: 22014414 
11. Reis JP, Loria CM, Lewis CE, PowellWiley TM, Wei GS, Carr JJ, et al. Association between duration of overall and abdominal obesity beginning in young adulthood and coronary artery calcification in middle age. Journal of the American Medical Association 2013; 310:280.

https://doi.org/10.1001/jama.2013.7833

PMid: 23860986 PMCid: PMC4226407

12. Stabouli S, Kotsis V, Karagianni C, Zakopoulos N, Konstantopoulos A.lBlood pressure and carotid artery intima-media thickness in children and adolescents: the role of obesity. Hellenic Journal of Cardiology 2012; 53:41-7.

13. Le J, Zhang D, Menees S, Chen J, Raghuveer G. "Vascular Age" is advanced in children with atherosclerosis-promoting risk factors. Circulation: Cardiovascular Imaging 2010; 3: 8-14.

https://doi.org/10.1161/CIRCIMAGING.1 09.880070

PMid: 19920030

14. Kollias A, Psilopatis I, Karagiaouri E, Glaraki M, Grammatikos E, Grammatikos EE, et al. Adiposity, blood pressure, and carotid intima-media thickness in Greek adolescents. Obesity 2013; 21:1013-7.

https://doi.org/10.1002/oby.20194

PMid: 23784905

15. Osiniri I, Sitjar C, Soriano-Rodríguez P, Prats-Puig A, Casas-Satre C, Mayol L, et al. Carotid intima-media thickness at 7 years of age: Relationship to C-reactive protein rather than adiposity. The Journal of Pediatrics 2012; 160:276-80.e1. https://doi.org/10.1016/j.jpeds.2011.07.02 0

PMid: 21875718
16. Böhm B, Hartmann K, Buck M, Oberhoffer R. Sex differences of carotid intima-media thickness in healthy children and adolescents. Atherosclerosis 2009; 206:458-63.

https://doi.org/10.1016/j.atherosclerosis. 20 09.03.016

PMid: 19389672

17. Baroncini LA, Sylvestre L de C, Pecoits Filho R. Assessment of intima-media thickness in healthy children aged 1 to 15 years. Arquivos Brasileiros de Cardiologia 2016; 106(4):327-32.

https://doi.org/10.5935/abc.20160030 PMid: 26959401 PMCid: PMC4845706

18. Park MH, Skow A, De Matteis S, Kessel AS. Saxena S, Viner RM, et al. Adiposity and carotid-intima media thickness in children and adolescents: a systematic review. BMC Pediatrics 2015; 15:161-5. https://doi.org/10.1186/s12887-015-04785

PMid: 26475608 PMCid: PMC4609088 